УДК:351/354:351.9

DOI: https://doi.org/10.32689/2618-0065-2019-2/1-21-41

Говорун Сергій Васильович, кандидат наук $з$ державного управління, e-mail: gsvgrupp@ukr.net, тел.: (066) 367-08-76

ORCID: 0000-0001-9566-160X

\title{
ТЕОРЕТИКО-МЕТОДОЛОГІЧНІ ЗАСАДИ ДЕРЖАВНОГО УПРАВЛІННЯ У СФЕРІ ЗАБЕЗПЕЧЕННЯ ПОЖЕЖНОЇ БЕЗПЕКИ В УКРАÏHI
}

Анотація. У статті розглянути основні методологічні підходи до здійснення державного управління у сфері пожежної безпеки в Україні. Визначено функцію корисності для державного управління у СЗПБУ для кожного із методологічних підходів, при цьому повністю несприйнятливим для цілей державного управління у сфері що розглядається визнано метода аналізу ієрархій, який заснований на використанні суб'єктивних суджень експертів. Між тим, розгляд інших методологічних підходів до державного управління у сфері забезпечення пожежної безпеки - праксеологічного, ризик-орієнтованого й аудит-орієнтованого, вказує на те, що, незважаючи на той факт, що кожен з них має свої вади та переваги, необхідно їх спільне застосування, а не протипоставлення один одному як це робиться на сьогодні у науковій літературі та нормативно-правовій законодавчій базі України.

Доведено, що тільки органічне поєднання всіх трьох названих методологічних підходів, дасть максимальну користь державному управління у сфері пожежної безпеки в Україні, щодо зменшення негативних наслідків від пожеж та інших надзвичайних ситуацій, що пов'язані з ними.

Визначено функцію корисності кожного із розглянутих методологічних підходів. Побудовано модель системного методологічного підходу до державного управління у СЗПБ в Україні. Запропоновано авторський термін для «єдність в різноманітті», для визначення системоутворюючого чинника, що сприяє підвищенню емерджентності системи.

Автор доходить до думки, що визначальним та таким, що завдає напрямок діяльності та розвитку всього державного управління у сфері пожежної безпеки в Україні, повинен бути активний, праксеологічний підхід, як такий, що є основним вектором динаміки роботи всієї системи державного управління.

Ключові слова: праксеологічний підхід, аудит, ризик-орієнтований підхід, функція корисності, страхування, модель системного підходу, ризик, ліцензіат, стандарт безпеки, стандарт якості, ISO. 
Govorun Sergii Vasilyevich, $\mathrm{PhD}$ in Public Administration, e-mail: gsvgrupp@ukr.net, tel: (066) 367-08-76

ORCID: 0000-0001-9566-160X

\title{
THEORETICAL AND METHODOLOGICAL PRINCIPLES OF PUBLIC ADMINISTRATION IN THE FIELD OF FIRE SAFETY IN UKRAINE
}

\begin{abstract}
The article deals with issues the main methodological approaches to the implementation of public administration in the field of fire safety in Ukraine. The utility function for public administration in the field of fire safety in Ukraine for each of the methodological approaches is determined, while the method of analysis of hierarchies, which is based on the use of subjective judgments of experts, is completely unacceptable for the purposes of public administration in the considered sphere. Meanwhile, the consideration of other methodological approaches to public safety management in the field of providing fire safety praxeological, risk-oriented and audit-oriented, indicates that, despite the fact that each of them has its drawbacks and advantages, they need to be joint application, rather than opposition to each other, as is currently the case in the scientific literature and legislative and regulatory framework of Ukraine.

The author claim that only an organic combination of all three of these methodological approaches will maximize the benefits to public administration in the field of fire safety in Ukraine, in order to reduce the negative consequences of fires and other emergencies associated with them.

The utility function of each of the considered methodological approaches is determined. The model of the systematic methodological approach to public administration in the SOUP in Ukraine was constructed. The author's term for "unity in diversity" has been proposed, to determine the system-forming factor that contributes to the increase of the system's emergence.

The author comes to the conclusion that a pro-active, praxeological approach, which is the main vector of the dynamics of the work of the whole system of public administration, should be a decisive and determinant of the activity and development of the entire state management in the field of fire safety in Ukraine.
\end{abstract}

Key words: praxis approach, audit, risk-oriented approach, utility function, insurance, model approach, risk, licensee, security standard, quality standard, ISO.

Постановка проблеми. Виникнення нових загроз таких як терористичні атаки, гібридні війни, зміна економічної системи України, 
запровадження при цьому європейських стандартів управління та підходів для забезпечення пожежної безпеки, виведення на перший план забезпечення потреб особи громадянина України у захисту та особистій безпеці як першочергового завдання державного управління, вимагає запровадження нового методологічного підходу до розгляду способів та методів на яких базується функціонування системи забезпечення пожежної безпеки в Україні. Застосування не тільки якісних, часто суб'єктивних суджень, а і залучення математичного кількісного інструментарію для оцінки ризиків, розрахунок ймовірностей виникнення пожеж i надзвичайних ситуацій (подій) $\mathrm{y}$ практичну діяльність органів державної влади є досить актуальними.

Аналіз останніх публікацій за проблематикою. Проблеми державного управління у сфері пожежної безпеки на загальнодержавному рівні, розуміння сутності ризик-орієнтованого підходу на основі визначення ймовірностей настання тих чи інших подій, створення системи інформаційно-аналітичного забезпечення загальної та галузевої діяльності органів державного управління, проблеми страхування від пожежних ризиків, висвітлювали такі науковці, як: І.М. Абдурагімов, М.В. Андрієнко, С.О. Андрєєв, Б.М. Гамалюк, З.Г. Гонтар, І.П. Кринична, В.О. Костенко, О.В. Міллер, С.О. Романенко, В.В. Тютюник.

Вони з позицій різних методологічних підходів досліджували державне управління у сфері забезпечення пожежної безпеки в Україні. Аналіз наукового доробку названих науковців, а також інших дослідників проблеми державного управління у сфері, що розглядається у даній статі, дозволив виявити доволі цікаві тенденції, та окреслити основні методологічні підходи, які існують наразі у науковій думці щодо того базису на якому грунтується побудова всіх теоретичних і практичних підходів у сфері забезпечення пожежної безпеки в Україні.

Відтак, існує нагальна потреба у систематизації існуючих методологічних підходів, основних із яких, ми повинні зупинитися більш детально.

Формулювання цілей (мети) статті. Розглянути основні методологічні підходи до здійснення державного управління у сфері пожежної безпеки в Україні, визначити функцію корисності для державного управління у СЗПБУ для кожного із методологічних підходів, що будуть розглядатися та можливість їх практичного застосування.

Виклад основного матеріалу. «На сьогодні методологічний підхід до розгляду СЗПБУ засновано на традиційних методах класичного планування необхідної кількості сил та засобів, котрі необхідні для функціонування цієї системи. При цьому як методологічно визначив Т.Л. Сааті - «класичне рішення проблеми означає, що існує раніше складений план дій, котрий передбачає чітку послідовність тих чи інших дій різних органів управління, для уявної ситуації, що не відповідає тим надзвичайним ситуаціям, котрі виникають у реальному житті» $[1$, с.16]. Такий підхід не відповідає вимогам 
сьогодення, а саме тим сучасним викликам, котрі виникають останнім часом у світі, що швидко змінюється» [2, с.22].

Стратегією реформування системи ДСНС України визначено, що на третьому етапі їі реалізації (2019 - 2020 роки) передбачається запровадження системи управління техногенною та пожежною безпекою на основі ризикорієнтованого підходу і європейських стандартів щодо оцінювання і аналізу ризиків пожежної та техногенної безпеки суб'єктів господарювання [3]. То ж розглянемо сутність РОП і те які вигоди він може дати для безпеки держави та державному управлінню у СЗПБ.

Згідно до ст.1 Закону України «Про основні засади державного нагляду (контролю) у сфері господарської діяльності» - «ризик це ймовірність виникнення негативних наслідків від провадження господарської діяльності та можливий розмір втрат від них, що вимірюється у кількісних та якісних показниках» [4, ст. 1]. Ризик є добуток двох змінних: ймовірності настання тієї чи іншої події та можливих наслідків, тобто збитків, котрі можуть бути виражені у кількісних одиницях, таких як гривни, тони, кілограми, гектари, одиниці техніки або втрата людського життя чи заподіяння шкоди здоров'ю людини. Але ж при цьому виникає проблема із обчисленням кількості речовини, що потрапляють у атмосферне середовище, землю, воду у результаті пожежі.

Окреслена нами проблема виникає із того, що існуючі Методики обчислення шкідливих забруднюючих викидів у природне середовище розраховані на те що апріорно заздалегідь відомий начальний об'єм або кількість речовини яка горіла або вийшла 3-під контролю, а також відомий кінцевий об'єм або кількість цієї речовини. Різниця між цими двома показниками і складає обсяг вигорілої або такої, що потрапила у навколишнє середовище, речовини. Але ж всі ці Методики розраховані для тих об'єктів де ведеться жорсткий облік вихідних даних. У приблизно 97\% випадках загальної щорічної кількості пожеж в Україні, пожежі стаються там, де немає такої чіткої системи обліку та контролю, а відтак отримання достовірних даних про об'єм або кількість речовин що потрапила у атмосферне середовище, землю, воду або вийшла з-під контролю неможливо.

Практичні заміри кількості виділеної у природне середовище забруднюючої речовини на пожежах у режимі реального часу не проводяться, а створення такої системи оперативного реагування для відбору проб повітря, води, землі безпосередньо на приблизно 60-90 тис. пожежах щорічно коштувало би державі суму непомірно більшу ніж вигоди від іiі функціонування. Щодо визначення грошових збитків - то тут при існуючому нормативно-правовому забезпечені пожежної безпеки в Україні, а також системі розслідування причин та наслідків пожеж, теж виникають численні труднощі, внаслідок чого суми матеріальних збитків, які щорічно розраховуються на підставі аналізу масиву даних карток про пожежу $є$ 
нерелевантними і не висвітлюють реальної картини із обсягом заподіяної шкоди на цих пожежах [5, с.127-128].

Дещо інша ситуація складається із розрахунком ймовірності настання тієї чи іншої події. Хоча в науковій літературі є багато наукових досліджень щодо розробки математичного апарату для розрахунку такої ймовірності, але ж ми хочемо звернути увагу саме на основоположне підгрунтя цієї методологічної проблеми, яке на нашу думку робить практичне застосування такого розрахунку дещо обмеженим.

«Ймовірність настання тих чи інших подій можна визначити за допомогою теорії ймовірностей та математичної статистики (далі - ТВМС). Тому застосування ТВМС в процесі державного управління системою забезпечення пожежної безпеки, управлінням цивільної захистом, процесами запобігання виникненню катастроф природно-техногенного характеру, зниженню ймовірності виникнення непередбачуваних ризиків, може бути 3 деякими допущеннями та осторогами прийнято для прогнозування, планування та управління ними.

Такий підхід до визначення ризиків, має, на наш погляд, обмеження, тому що коректно розрахувати ймовірність тієї чи іншої події можна лише тоді, коли виконується така умова щодо неї, як: «події, що розглядаються, повинні бути наслідками тільки тих випробувань, які можуть бути відтворені необмежену кількість разів при одному і тому ж комплексі умов», тому що «статистичне визначення теорії ймовірності, як і поняття та методи теорії ймовірності в цілому, застосовні не до будь-яких подій 3 невизначеним результатом, які у життєвій практиці вважаються випадковими, а тільки до тих із них, які мають певні властивості» [6, с.21]. Першою такою і головною властивістю є відтворення певного комплексу умов.

«Такий розрахунок може мати місце і доречний там, де застосовуються стандартизовані вироби, що мають заздалегідь відому ймовірність відмови, для яких побудовані «дерева подій» та «дерева відмов», там де існує велика база статистичних даних, щодо настання тих чи інших подій для цих виробів, котрі у свою чергу багаторазово були перевірені на випробувальних стендах і для них отримані певні статистичні дані щодо статистичної ймовірності настання тієї чи іншої небажаної події, а також математичного очікування випадкової величини наприклад - часу роботи цього виробу. Тоді із сукупності цих ймовірностей можна судити про ймовірність настання деякої події у сукупності. Такий метод розрахунку успішно застосовується на атомних електростанціях, де $\epsilon$ потужні програмно-апаратні комплекси iз спеціалізованими прикладним програмним забезпеченням систем підтримки управлінських рішень, які і виконують зазначений розрахунок ймовірностей» [2, с.23]. Також при цьому необхідною умовою $є$ обов'язкова наявність висококваліфікованих спеціалістів котрі знаються на тому, які самі дані потрібно вводити до програмного-апаратного комплексу, розуміють саму природу та сутність цих вихідних даних, а також розуміються на тому - як 
правильно їх інтерпретувати, тому що саме правильне інтерпретування статистичних даних $\epsilon$ запорукою правильно проведеного статистичного аналізу, про що і наголошував Дж. У. Тьюкі (1977) [7].

«Для того, щоб побудувати дерево відмов того чи іншого виробу, що може призвести до пожежі необхідно провести структурний аналіз об'єкта взагалі. Визначити його складові частини (приміщення, елементи устаткування, технологічні апарати, установки); визначити перелік елементарних небажаних подій (базисних подій), поєднання яких можуть призвести до пожежі (вибуху), для кожної базисної події визначити унікальний ідентифікатор; встановити причинно-наслідкові зав'язків між подією пожежа (вибух) i базисних подій i для цього потрібен звичайно експерт, котрий має високу спеціальну, математичну і пожежно-технічну підготовку» [8, с.48].

Наявність значного арсеналу технічних засобів та високоякісних експертів може дозволити собі лише фінансово потужна організація, керівництво якої насамперед розуміється в тому, що ціна допущеної помилки при прийнятті управлінського рішення $є$ дуже високою як із економічної точки зору, так і з погляду настання негативних наслідків техногенного та соціального характеру. Однак, саме по собі розуміння всієї небезпеки без наявності фінансово-економічних і технічних ресурсів, які включають у себе наявність означених висококваліфікованих експертів, не дасть нічого, крім відчуття власної неспроможності вирішити нагальні питання безпеки.

«Але ж неможливо залучити до розрахунку ймовірності настання базисної події (пожежі), скажімо, у маленькій перукарні чи у звичайній житлової квартирі пересічного громадянина, що знаходиться у будівлі, яка була побудована 20, 50 або 100 років тому, такого потужного технічного i людського ресурсу, як, наприклад, на атомній електростанції» [2, с.23]. До того ж абсолютно невідомо, із яких компонентів складається технічне наповнення даної перукарні або житлової квартири. Абсолютно невідомий закон, за яким розподілена випадкова величина для складових частин таких об'єктів (по кожній групі) і неможливо коректно визначити їі практично на даному етапі за існуючої системи збору, обліку і передачі інформації із причин пожеж та наслідків від них. Тим більше, що ймовірність настання такої події, як підпал, не відома. Також взагалі не можна передбачити, де, як i 3 яким початковим масштабом відбудеться пожежа, тому що на іiі розвиток особливо в початковій фазі впливають багато взаємопов'язаних факторів. Питання прогнозування настання таких подій взагалі виходять за рамки класичної ТВМС та взагалі нами не розглядаються.

До того ж, за визначенням В. фон Гейзенберга (1989), «функція ймовірності не описує сам перебіг подій у часі. Вона характеризує тенденцію події, можливість події або наше знання про подію. Функція ймовірності зв'язується 3 дійсністю тільки при виконанні однієї істотної умови: для 
виявлення певної властивості системи необхідно провести нові спостереження або вимірювання» [9, с.21].

Тим більше, що сам факт настання якої-небудь події (пожежі або надзвичайної ситуації) змінює ймовірність настання нової такої події (пожежі або надзвичайної ситуації, таким чином, ми у своїх математичних моделях та розрахунках входимо до «зони» розв’язання задач в умовах невизначеності, але ж ніяк не ризику. У цьому, на нашу думку, полягає велика фундаментальна різниця між побудовою математичних моделей для вирішення управлінських задач та самим прийняттям управлінських рішень, які здійснюються в умовах невизначеності або в умовах ризику. Необхідно особливо зауважити, що «вкрай важливо застосовувати правильну модель у кожній конкретній ситуації, а якщо ми будемо застосовувати неправильну модель, ми можемо отримати ідеальне математичне рішення помилково поставленої задачі» [10, с. 222].

Повертаючись до питання відтворення «одного і того ж комплексу умов», необхідно зауважити, що в реальному житті неможливо відтворити такий «комплекс умов» для людини, яка один раз у житті потрапляє до пожежі». Або як можна чітко окреслити рішення такої проблеми, наприклад, як ліквідація виниклої пожежі, та здійснити розрахунок ймовірності іiі успішної ліквідації або розрахувати математичне очікування часу іiі ліквідації, яка, наприклад сталася на промисловому підприємстві 3 виробництва вибухонебезпечних або сильнодіючих отруйних речовин, де діють безліч чинників і невідомих випадкових величин у початковий момент часу іiі виникнення та тих чинників, що динамічно діють у самому перебігу такої події та призводять до нелінійного розвитку процесу горіння, при цьому багатократно ускладнюється сама методологія побудови математичного апарату задля математичного аналізу такої події. Передбачити ж проектним розрахунком, що саме, де, коли, як та 3 якою інтенсивністю буде впливати у разі виникнення критичної ситуації на той або інший технологічний апарат або будівельну конструкцію чи технологічний процес у цілому, або на комплекс будівель і споруд, наявними в даний час методами, засобами і способами неможливо» [2, с.24].

За визначенням Т.Л. Сааті «неможливо визначити теперішнє 3 достатньою точністю, щоб передбачити майбутнє» [6, с.19]. Але ж, основна ціль розрахунків покладених у основу РОП - передбачення майбутнього. Таким чином, ми дійшли до колізії у самій суті проведення розрахунку ймовірностей виникнення пожежі для забезпечення існування РОП, який вказує по-перше - на наявність часового лагу у визначені ймовірності настання тієї чи іншої події сьогодні та у майбутньому, а по-друге - на наявність великої похибки у числових розрахунках ймовірності настання тих чи інших подій.

«Тому на наш погляд основні положення і прийоми, що застосовуються у ТВМС, є важливими методами у подальшому розгляді описаних процесів 3 
метою їх вивчення і практичного втілення у теорію державного управління у СЗПБ в України з метою запобігання виникненню таких ризиків, як аварії на атомних електростанціях, оцінювання ймовірності настання пожеж по окремій галузі господарства або в межах країни в цілому, досліджуючи їх у генеральній сукупності, але ж, як було показано, вони практично незастосовні до здійснення розрахунку ризиків на інших окремих об'єктах, як вибіркових ознак із всієї множини подій генеральної сукупності» [2, с.25].

Необхідно зазначити, що метод, покладений в основу РОП, являє собою фотографічний знімок існуючого стану речей, як відбиток статичного стану природи у деякий конкретний момент. А відтак - сьогодні відбиток має один вигляд (маємо на увазі числові показники), завтра - інший, а учора він був не схожим на два попередніх. Тому, використовуючи його в теорії та практиці державного управління у СЗПБ, на наш погляд, неможливо отримати динамічне уявлення про реальний стан із забезпечення пожежної безпеки у реальному часі.

За своєю природою РОП виходить зі статистичних методів ТВМС, які історично виникли для вирішення практичних питань отримання виграшу в азартних іграх, таких як рулетка, кості та карти. Тому всі класичні визначення ТВМС спираються, як ми вже показали, на можливість відтворення експерименту в одних і тих умовах, що неможливо в реальному житті, оскільки нам невідомі об'єктивні закони, які супроводжують настання небажаних і небезпечних подій, таких як пожежі й надзвичайні ситуації.

Нам невідомий механізм їх виникнення, тому неможливо отримати жодним математичним моделюванням об'єктивні ймовірності щодо їх настання, хоча варто зазначити, що «методи теорії ймовірностей не відміняють і не скасовують випадковості, непередбачуваності результату окремого досвіду, але дають можливість передбачити, 3 деяким наближенням, середній сумарний результат маси однорідних випадкових явищ. Чим більша кількість однорідних випадкових явищ фігурує в задачі, тим виразніше виявляються властиві їм специфічні закони, тим із більшою впевненістю та точністю можна здійснювати науковий прогноз.

«Мета імовірнісних (статистичних) методів в тому, щоб, минаючи занадто складне (i часто практично неможливе) дослідження окремого випадкового явища, звернутися безпосередньо до законів, що керують масами таких явищ. Вивчення цих законів дозволяє не тільки здійснювати прогноз в області випадкових явищ, а й цілеспрямовано впливати на хід цих явищ, контролювати їх, обмежувати сферу дії випадковості, звужувати іiі вплив на практику» [11, с.11-12]. Таким чином, ми доходимо висновку, що методи покладені у основу застосування РОП мають всі ознаки нормативної теорії, яка «має рекомендаційний характер для тих, хто приймає рішення» [10, с.18] та «є необхідним при здійсненні розрахунків щодо страхування ризиків від настання відповідних страхових випадків, як то пожежа або надзвичайна ситуація, тому що він використовує методи ТВМС. Але ж, 
звертаючись до сутності самої страхової справи, ми повинні зазначити, що «страхування - один із найбільш використовуваних методів фінансування ризиків, який належить до процедури передачі ризиків. Сутність цього методу полягає в передачі відшкодування можливих збитків іншому суб'єкту, що спеціалізується на таких операціях, - страховій компанії. Використання страхування означає зниження участі, а іноді навіть повну відмову самої фірми (страхувальника) від участі у покритті збитків за рахунок перекладання свого ризику на страхову компанію за певну плату» $[12$, c. 77$]$.

У такому разі ми мусимо зазначити, що РОП у поєднані зі страхуванням, як одним із найбільш застосовуваних методів управління ризиками, носить характер пасивної складової методів державного управління у СЗПБ. Зазначений метод розрахунку ризиків відповідає вимогам міжнародну стандарту ISO/IEC 31010:2009 «Менеджмент ризику. Методи оцінки ризиків. (Risk management. Risk assessment techniques)» [13].

Якщо неможливо отримати достовірні i релевантні об'єктивні ймовірності, які відповідають реальній дійсності й стану справ, то залишається сподіватися на отримання суб’єктивних суджень. «Тут можна було б запропонувати застосування методу аналізу ієрархій, призначеного для багатокритеріального прийняття рішень на основі обробки суб'єктивних суджень експертів або експертних оцінок, що базується на трьох принципах: 1) декомпозиції; 2) вимірювання переваг; 3) синтезу пріоритетів. Декомпозиція дозволяє уявити проблему за допомогою безлічі взаємопов'язаних елементів, кожен з яких розглядається окремо. Узагальнене розуміння мети деталізується описами критеріїв (станів природи) термінами якими оцінюється рішення. Результатом декомпозиції $\epsilon$ багаторівнева ієрархічна структура, де однорідні елементи згруповані в рівні (компоненти) таким чином, щоб їх можна було оцінити за важливістю або впливу щодо елементів суміжних рівнів. Вимірювання елементів виконується 3 використанням шкали відносин, яка виходить з парних порівнянь елементів одного рівня ієрархії щодо впливу елементів вищерозташованого ієрархічного рівня» [6, с. 266].

Зважаючи на це, першим із глобальних пріоритетів у такій композиції повинно було б стати збереження людського життя та іiі здоров’ я, іiі особиста безпека і захищеність. I в цьому, на наш погляд, мав би бути здійсненний саме перехід до європейських стандартів забезпечення безпеки людського існування, про які ми згадували на початку нашого дослідження. Державне управління взагалі, у СЗПБ зокрема, повинне слідувати меті, яка задекларована у Конституції України та визначає, що «обов’язок держави захищати життя людини» [14, ст. 27], а також те, що «людина, іiі життя i здоров'я, честь і гідність, недоторканність і безпека визнаються в Україні найвищою соціальною цінністю» [14, ст. 3]» [2, с.25]. 
Питання формулювання та висловлення людиною власних суб'єктивних суджень, їх ранжування, присвоєння їм вагових оцінок $\epsilon$ набагато більш суб'єктивним і вельми залежить від зовнішніх факторів, котрі діють безпосередньо на цю окрему людину у конкретний момент часу, при здійснені нею зазначеної мозкової активності. До того ж кожна людина володіє певним набором фільтрів свідомості, що були набуті нею за іiі життя, і чим довше це життя - тим на жаль людина має більше таких фільтрів свідомості, які насправді заважають приймати вірні рішення.

Зауважимо, що - вірне рішення не завжди відповідає тому правильному рішенню котре повинна прийняти людина. Людина приймає правильне рішення для себе, виходячи із того, що вона свідомо або несвідомо максимізує для себе свою власну функції корисності. I тільки іiі власний людський розсуд у даний конкретний момент часу може визначити, що для цієї людини є максимізацією функції корисності. Тим більш, що не завжди рішення, що приймаються людьми мають ідеалізовану та абстраговану від зовнішніх обставин природу.

Велику роль при цьому відіграє схильність людини до конформності. У кожної людини є свій рівень конформності, тобто рівень слідування за іншими людьми або за групою людей. При чому цей рівень, як було показано Е. Аронсоном та ін. (2002) [15], змінюється впродовж життя людини. Тому ми не можемо також бути впевненими, що один і той же експерт, який застосовує у своїй роботі метод аналізу ієрархій, на протязі якого-небудь проміжку часу буде генерувати такі рішення, котрі залежать тільки від його особистого розсуду і його особистої уяви, та які будуть схожими між собою у різні моменти часу та за різних обставин.

Також при цьому постає не менш важливе практичне завдання для державного управління - щодо наявності необхідної кількість настільки підготовлених у теоретичному аспекті експертів, які будуть мати при цьому необхідний практичний досвід у сфері питань, що їм доведеться вирішувати, i чи зможемо бути ми впевненні у їх необхідній кваліфікації, чесності та неупередженості при прийнятті рішень. Чи будуть вони зацікавлені та достатньо вмотивовані для прийняття вірних рішень по тим нагальним проблемам для вирішення яких вони будуть залучені. Не останню роль відіграє тут і факт непідкупності людини, відсутності у неї конфлікту інтересів щодо вирішуваного нею питання, тощо.

Особливо актуальним ці питання постають у світі децентралізації влади в Україні, коли все більше i більше повноважень, щодо прийняття повсякденних, нагальних питань у державному управлінні передається до відома ОМС. Створення спроможних ОТГ, а також необхідність вирішення задач державного управління, в тому числі і задач державного управління у СЗПБ на територіальному рівні вимагає у такому разі залучення великої кількості кваліфікованих експертів, яким будуть притаманні всі вже описані нами негативні властивості, за яких не будуть прийняти вірні рішення. 
Станом на 24.06.2019p. в Україні створено 913 ОТГ, із яких 102 ОТГ перші вибори ще не відбулися. Загальна кількість рад у цих ОТГ складає 4157 одиниць, кількість населення складає 9 млн 706 тис. 047 осіб, загальна площа яку займають ОТГ становить 217 тис 075,35 км² [16]. Виходячи із цих даних, ми наявно бачимо, що вже майже на третині території України сформовані та діють ОТГ, яким необхідно за умов децентралізації на власний розсуд вирішувати проблеми державного управління у СЗПБ. А як відомо, для отримання релевантних оцінок для вирішення задач методом аналізу ієрархій, необхідно мати групу хоча б із 5-7 осіб. Тож тоді ми маємо попередню розрахункову кількість експертів приблизно від 4565 до 6391 осіб, при цьому потреба у підготовлених фахівцях буде нестримно зростати зі збільшенням кількості ОТГ в Україні.

Сьогодні немає відповідної матеріально-технічної бази для підготовки такої кількості фахівців у галузі прийняття рішення методом аналізу ієрархій, яка відповідала б реальним потребам сьогодення, що пред'являються із боку ОТГ і відповідають сучасним викликам у СЗПБ, які треба долати на місцевому рівні.

ДСНС України сьогодні не в змозі провести навчання голів ОТГ та їх заступників щодо організації громадського порядку та здійснення заходів щодо запобігання пожежам, розроблення планів цивільного захисту відповідних територій, організації добровільних пожежних підрозділів, відбору на службу до них добровільних пожежних і таке інше. Натомість цим наразі опікується іноземна компанія «GIZ GmbH» у рамках програми «ULEAD з Свропою: Програма для України з розширення прав і можливостей на місцевому рівні, підзвітності й розвитку» [17].

Тому, на наш погляд, застосування у державному управління методу заснованого на використанні суб'єктивних суджень, зокрема, методу аналізу ієрархій, запропонованого Т.Л. Сааті та розвинутого Л. Варгасом $є$ недоречним і методологічно невиправданим.

Наступним методологічним підходом у державному управлінні у СЗПБ, є підхід, який являє собою активний цілеспрямований вплив суб'єктів державного управління на об'єкти управління та полягає у здійсненні активних кроків такими суб'єктами щодо стимуляції об'єкта управління, у тому числі здійснення заходів направлених на заохочення об'єкта управління, шляхом надання економічних і податкових преференцій, для мотивації об'єкта управління на виконання ним певних керуючих впливів, тобто розпоряджень, приписів, рекомендацій і т.д, які, виконані повністю чи хоча б частково, призведуть до підвищення рівня пожежної безпеки та зниження ризику виникнення надзвичайної ситуації на об'єкті управління.

Тут обов'язково необхідна наявність петлі «негативного зворотного зв'язку», при якому зміни в об'єкті управління, що виникли внаслідок цілеспрямованого управлінського впливу на нього суб'єкта управління, призводять до змін в управлінському впливі, що виходить від останнього, 
тільки 3 оберненням на протилежний знак такого впливу. Наприклад, підвищення рівня пожежної безпеки об'єкта управління повинне призводити до зменшення сили управлінського впливу, який виходить від суб'єкта управління. I навпаки - якщо здійснюваних заходів щодо зменшення пожежної безпеки об'єкта управління недостатньо і вона продовжує зменшуватися або залишається на тому ж рівні, що теж необхідно розглядати як сигнал до збільшення сили управлінського впливу, суб'єкт управління повинен вжити всіх необхідних заходів щодо досягнення кінцевої мети своєї управлінської діяльності у СЗПБ - збільшення ступеня пожежної безпеки об'єкта управління, який зі значними припущеннями можна оцінювати за критеріями величини ризику виникнення пожежі на ньому або іншої надзвичайної ситуації.

Методологія визначення таких критеріїв для кожного із об'єктів управлінського впливу або їх групи, що формується за деякими спільними для цих об'єктів ознаками, ще потребує свого осмислення (які об'єкти, їх спільні класифікаційні ознаки, за якими ознаками слід провадити групування i т.д) та математичного моделювання. Але ж це повинно провадитися за більш розподіленими і диференційними критеріями ніж це відбувається наразі. Прикладом для визначення таких критеріїв може бути запозичена $\mathrm{i}$ розвинена система Великої Британії.

На наш погляд, практичні дії органів управління повинні відбуватися за чітким алгоритмом. Це показує В.О. Костенко (2017), який запропонував алгоритм трасування державного управління у сфері захисту населення в умовах надзвичайних ситуацій. Також ним було запропоновано такий підхід, відповідно до якого «діяльність суб'єктів управління має бути спрямована на жорсткий покроковий процес розроблення керівних впливів на керовані підсистеми з метою досягнення максимальної ефективності дій за певних умов відповідно до отриманого завдання 3 вищого рівня управління процесом узгодження дій системи за місцем, часом, виконавцями, ресурсами, що вказує на послідовність дій у складних ділянках трасування, контролюючи результат з векторизації ланцюга та правил трасування» [18, c.34].

Таким чином, ми бачимо, що такий методологічний підхід носить характер активної складової методів державного управління у СЗПБ, а методи покладені у його підгрунтя мають всі ознаки дескриптивної теорії, котра у свою чергу «описує реальність - як вона є» [10, с. 18], на відміну від згаданої нами раніше нормативної теорї, яка застосовується при запровадженні РОП.

Але ж існує ще один методологічний підхід до державного управління у СЗПБ, який заснований на проведені незалежного аудиту стану пожежної безпеки об'єкта управління спеціалізованими аудиторськими фірмами або фізичними особами - підприємцями. 
Згідно з чинним Законодавством України, така діяльність провадиться організаціями, які отримали Ліцензію на право здійснення у СЗПБ такої діяльності згідно до Закону України від 02.03.2015 №222-VIII «Про ліцензування видів господарської діяльності» [19].

Згідно до п.3 ст.1 Закону №222-VIII - «ліцензіат, це суб'єкт господарювання, який має ліцензію на провадження встановленого законом виду господарської діяльності». Перелік видів господарської діяльності, що підлягають ліцензуванню надається у статті 7 даного законодавчого акту. У відповідності до п.13 статті 7 ліцензуванню підлягає в тому числі і «надання послуг і виконання робіт протипожежного призначення за переліком, що визначається Кабінетом Міністрів України». Таким чином законодавець на вищому рівні встановив вимоги щодо необхідності обов'язкового отримання ліцензії суб'єктом господарювання для цілей забезпечення послуг і робіт у СЗПБ.

Прийнятою Кабінетом Міністрів України Постановою № 852 від 23.11 .2016 p. були затверджені «Ліцензійні умови провадження господарської діяльності 3 надання послуг i виконання робіт протипожежного призначення», a також «Перелік послуг i робіт протипожежного призначення, що підлягають ліцензуванню». У п.7 даного переліку зазначено, що ліцензуванню підлягає «оцінка (експертиза) протипожежного стану новоутворених підприємств та об'єктів нерухомості (будівель, споруд, приміщень або їх частин)». У п.35 «Ліцензійних умов...» зазначено, що «за результатами оцінки протипожежного стану визначається відповідність новоутворених підприємств та об'єктів нерухомості (будівель, споруд, приміщень або їх частин) вимогам правил пожежної безпеки» [20].

Тому оцінка (експертиза) протипожежного стану, або як це окреслюється у науковому середовищі «аудит з пожежної безпеки» [21, 22], $\epsilon$ частковим втіленням у вітчизняну практику забезпечення системної безпеки міжнародного стандарту OHSAS 18001:2007 «Системи менеджменту охорони здоров'я та забезпечення безпеки праці» [23], а також міжнародного стандарту ISO/IEC 31010:2009 «Менеджмент ризику. Методи оцінки ризиків (Risk management - Risk assessment techniques) [13]. Стандарт OHSAS 18001:2007 «Системи менеджменту охорони здоров'я та забезпечення безпеки праці» визначає, що «аудит (audit) - систематичний, незалежний i такий, що документується, процес отримання «свідчень аудиту» (audit evidence) та їх об'єктивного оцінювання для визначення ступеня відповідності «критеріям аудиту» (audit criteria) [23, п. 3.2]. Детальне роз'яснення цих термінів наведене у стандарті якості ISO 19011:2011 [24]. Зазначимо, що станом на 16.02.2019 р., за даними порталу електронних послуг ДСНС [25], в Україні нараховується 207 ліцензіатів 142 ліцензіата, що провадять свою діяльність із оцінки (експертизи) протипожежного стану новоутворених підприємств та об'єктів нерухомості (будівель, споруд, приміщень або їх частин). 
Необхідно зазначити, що у порівнянні із початком 2019 року кількість ліцензіатів за даним видом послуг зросла майже у півтора рази (із 142 станом на 16.02.19 р. до 207 станом на 24.06.19p.). Абсолютний приріст складає 65 ліцензіатів (169 юридичних та 38 фізичних осіб) або 45,77 \% за чотири місяці поточного 2019 року [25].

Для практичного втілення цих стандартів у практику розроблено стандарт ISO 19011:2011 «Керівництво по аудиту систем менеджменту» [24, c.2], який описує механізми роботи системи аудиту, ії структурнофункціональні схеми, тощо. Згідно з цим стандартом, аудит може бути як внутрішній, так і зовнішній, при чому зовнішній аудит поділяється на «аудит другою стороною» або «аудит постачальника» та «аудит третьою стороною», який застосовуються у правових, регуляторних та подібних цілях. Саме «аудит третьою стороною» становить інтерес для розгляду методологічних засад державного управління у СЗПБУ.

Проаналізувавши зміст і сутність наведених міжнародних стандартів, що регламентують аудиторську діяльність, ми можемо зробити висновок, що аудит за своєю сутністю - 1) не є обов'язковим; 2) не тягне за собою у разі його проведення обов'язкового накладання санкцій; 3) може проводитися «за бажанням», тобто за взаємною згодою сторін; 4) містить у своїх свідченнях і даних аудиту системний аналіз ситуації, що склалася на об'єкті управління, де проводиться аудит; 5) дані аудиту можуть носити рекомендаційний характер. Таким чином, даний методологічний підхід носить характер нейтралізуючої складової методів державного управління у СЗПБ. Аудит $\epsilon$ різновидом або окремим випадком системи моніторингу стану пожежної безпеки.

Моніторинг стану пожежної безпеки, оскільки він не несе у собі активної складової, тобто не здійснює позитивного корегуючого впливу безпосередньо на об'єкти управління, $\epsilon$ нейтралізуючим підходом до здійснення державного управління у СЗПБУ подібно до страхування, яке у свою чергу, як ми вже проаналізували, обслуговують методи визначення ймовірності настання тих чи інших подій, що закладені у ризик-орієнтовному підході.

Моніторинг - це динамічне віддзеркалення у часі стану окремих об'єктів системи, iї складових або всієї системи взагалі, залежно від того обсягу інформаційної складової, яка поступає на вхід системи моніторингу.

Тому моніторинг, як методологічний підхід до державного управління у СЗПБ в Україні уявляється нам також нейтралізуючою складовою, як саме i методи, покладені в його підгрунтя, також мають усі ознаки дескриптивної теopiï.

Але ж як ми бачимо згідно до вимог викладених у ПКМУ від 23.11.16 p. № 852 [26], проведення аудиту обмежено на теренах України лише новоствореними або новопобудованими об'єктами та не поширюється на вже діючи об’єкти. Тут закладено протиріччя у визначені мети та завдань аудиту. 
Державне управління в цьому випадку встановлює монополію на проведення перевірок стану пожежної та техногенної безпеки для свого контролюючого органу - відповідної інспекції, що діє у складі ДСНС України. При цьому порушується умова необхідного балансу між трьома розглянутими вище підходами - активним, пасивним і нейтралізуючим, які повинні сходитися у єдиній точці прикладення вектору своєї дії (об'єкті управління) та входити один до одного і гармонійно взаємодіяти для отримання певного результату із мінімізації негативних наслідків реалізації небажаних подій, таких як пожежа або інша надзвичайна ситуація. Графічне зображення даного системного підходу наведено на рис. 1.

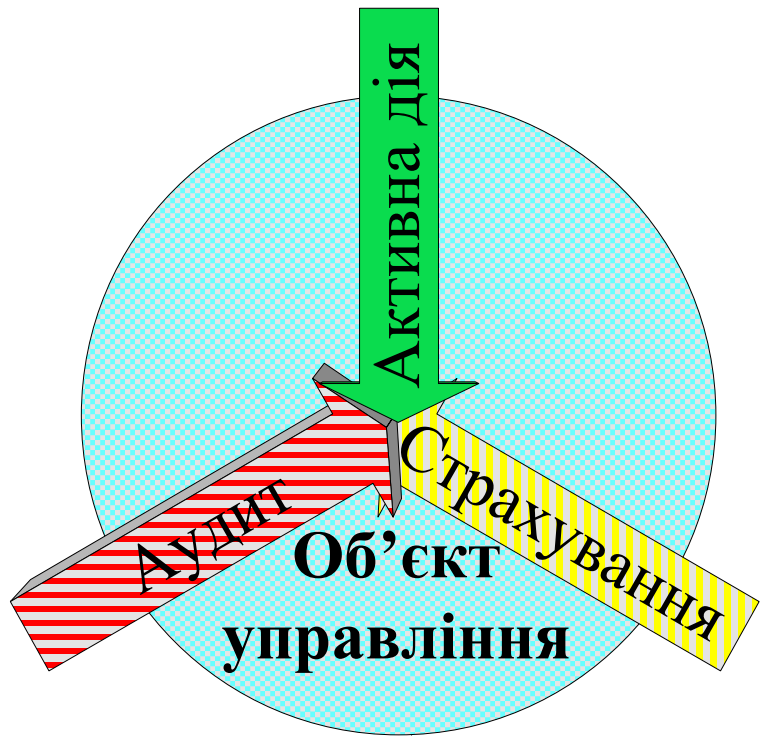

Рис. 1. Модель системного методологічного підходу до державного управління у СЗПБ в Україні.

Джерело: дослідження автора (5, с. 57)

Таким чином, розглянувши теоретичні та практичні підходи до здійснення державного управління у СЗПБУ, ми можемо стверджувати, що «ми повинні органічно та інтегровано застосовувати різні підходи до державного управління системою пожежної безпеки таким чином, щоб їх поєднання давало максимально ефективний результат, i цей результат повинен бути - збереження людського життя, здоров'я, самого її безпечного існування, збереженню її честі, гідності та недоторканності» [2, с.25].

Єдність, що полягає в різноманітті форм і методологічних підходів у державному управлінні у сфері пожежної безпеки - адміністративних, економічних, правових i т.д - дозволить забезпечити найвищий рівень безпеки об'єктів управління, які існують у даній сфері. Тільки така «єдність в різноманітті» дозволить забезпечити реальну їх об'єктивну безпеку на всіх рівнях - на рівні буття людини як індивіда, на рівні суспільства, соціуму, держави як в плані особистої безпеки, так і у фінансово-майновому плані. Не можна ні в якому разі протиставляти аудит, що проводиться на об'єктах 
управління в СЗПБУ приватними особами та організаціями, державному нагляду у зазначеній сфері, проведення профілактичних заходів в рамках пропагандистських, роз'яснювальних кампаній - практичній та повсякденній роботі із попередження пожеж (активних дій щодо зниженню та редукування пожежної небезпеки тих чи інших об'єктів і явищ), «жорстке» адміністративне управління - економічним мотивуючим і стимулюючим методам. Ігнорування об'єднання всіх цих методів в одному триєдиному державно-управлінському циклі може призвести до помилкових результатів і марнування зусиль і коштів на досягнення поставленої мети - забезпечення найвищого рівня безпеки в зазначеній сфері діяльності державного управління. Це, у свою чергу, може призвести до вкрай небажаних результатів, негативні відгуки яких, внаслідок існування часового лагу між здійсненням кроків у державному управління та отриманням певних виходів, будуть відчуватися ще багато років.

Висновки i перспективи подальших досліджень. Теоретикометодологічні підходи до здійснення державного управління у СЗПБ в Україні, мають три основних напрямки.

Активний підхід, що заснований на здійсненні активного державного управління у СЗПБ, щодо попередження пожеж, ліквідації пожеж та надзвичайних ситуацій, що спричинені ними, а також ліквідації їх наслідків. Такий підхід, передбачає, активну домінуючу роль державного управління, щодо визначення стану пожежної безпеки тих чи інших об'єктів, природноекологічних систем, територій, конгломератів, тощо. При цьому потрібно невпинне $\mathrm{i}$ цілеспрямоване здійснення державного управління по прогнозуванню, плануванню, координації, контролю за виконанням заходів, що направлені на активне попередження самого факту виникнення пожеж, а не очікування такого, як це передбачається ризик-орієнтованим підходом.

Пасивний підхід здійснення державного управління на основі ризикорієнтованого підходу, який $є$ віддзеркаленням статистичного стану природи речей і ніяким чином не віддзеркалює сам перебіг подій у часі. Саме знання про міру небезпеки ніяким чином не робить цю небезпеку меншою, а у довгостроковій перспективі, робить людину пасивної та байдужою до самої небезпеки. До того ж ті самі методи розрахунку ризиків, що покладені у його основу, є суттю й основою ведення страхової справи взагалі, на було вказано у дослідженні (Гамалюк Б.М., Говорун С.В, 2019) [27], а тому здійснення державного управління на основі тільки ризик-орієнтованого підходу тільки погіршить і до того незадовільний стан речей із забезпеченням пожежної безпеки в Україні, а його просування i протипоставлення на шкоду активному державному управлінню, є лобіюванням фінансових інтересів певних бізнес-структур (гравців страхового ринку).

Аудит із пожежної безпеки, який являє собою нейтралізуючу складову здійснення державного управління у СЗПБ в Україні, допомагає виявляти 
недоліки у стані протипожежного захисту, які із тих чи інших причин були упущені при здійсненні активного державного управління у зазначеній сфері, або при визначені ризиків виникнення пожеж.

Усі три підходи мають право на існування, однак у жодному разі не повинні протиставлятися один одному, навпаки - повинні бути органічно поєднані в одне ціле, доповнювати і перекривати один одного для досягнення єдиної мети державного управління у СЗПБ - недопущення виникнення пожеж та втрати на них людських життів і понесення матеріальних втрат. Даний показник доречно використовувати як індикатор ефективності й результативності здійснення державного управління у сфері пожежної безпеки. Кінцевою метою дії цих підходів має бути невпинне зниження ентропії об’єктів управління або міри невизначеності їх можливих станів, і як наслідок - постійне зниження кількості пожеж та спричинених ними надзвичайних ситуацій, а також постійне зниження кількості загиблих на цих пожежах людей і зменшення загального обсягу у негативних наслідків, таких як економічні та фізичні втрати, що були ними завдані [5, с. 78-79].

Таким чином, розгляд активного, пасивного, нейтралізуючого методологічних підходів до забезпечення державного управління у сфері забезпечення пожежної безпеки дозволив довести положення щодо доцільності їх комплексного застосування при домінуючій ролі активного (упереджувального, праксеологічного) підходу направленого на активну превенцію самого факту виникнення пожеж та інших надзвичайних ситуацій.

\section{Jimepamypa:}

1. Саати Т, Кернс К. Аналитическое планирование. Организация систем : Пер. с англ. - М.: Радио и Связь, 1991. - 224 с.: ил.

2. Говорун С.В. Прогнозування непередбачуваних ризиків у державному управління системою забезпечення пожежної безпеки : сутність та методи / Становлення публічного адміністрування в Україні : матеріали VIII Всеукр. міжвуз. конф. студентів та молодих учених // за заг. ред. С. О. Шевченка. - Д.: ДРІДУ НАДУ, 2017. - 355 с.

3. Розпорядження Кабінету Міністрів України № 61-р від 25.01.2017 року. Про схвалення Стратегії реформування системи Державної служби України з надзвичайних ситуацій [Електронний ресурс] - URL:

http://search.ligazakon.ua/l_doc2.nsf/link1/KR170061.html (дата звернення: 07.07.19)

4. Закон України «Про основні засади державного нагляду (контролю) у сфері господарської діяльності» / Офіційний вісник України від 25.06.2007 - 2007 р., № 44, стор. 12, стаття 1771, код акту 40114/200.

5. Говорун Сергій Васильович. Державне управління у сфері забезпечення пожежної безпеки в Україні: аспекти інституційного розвитку : дис. ... к. держ. упр. : 25.00.01 / Говорун Сергій Васильович. - Львів, 2019. - 279 с.

6. Саати Томас Л. Принятие решений при зависимостях и обратных связях: Аналитические сети. Пер. с англ. / Науч. ред. А. В. Андрейчиков, О. Н. Андрейчикова. М.: Издательство ЛКИ, 2008. - 360 с.

7. Дж. Тьюки. Анализ результатов наблюдений. Разведочный анализ. Пер. с англ. под общ. ред. В.Ф. Писаренко. - М. : Изд-во «Мир», 1981. - 697 с. 
8. Серебровский А.Н., Оксанич И.Н., Еременко Т.К., Пилипенко Ю.Г. Вероятностный анализ безопасности при оценивании степени пожарной опасности объекта / Науковий вісник УкрНДІПБ, 2015, № 1 (31). - С. 46-55.

9. Гейзенберг В. Физика и философия. Часть и целое: Пер. с нем. - М.: Наука. Гл. ред. физ.-мат. лит., 1989. 400 с.

10. Гильбоа, Ицхак. Как принять наилучшее решение. Теория принятия решений на практике / Ицхак Гильбоа; пер. с англ. Н.В. Шиловой; под науч. ред. М.И. Левина и В.П. Бусыгина. - М.: Издательский дом «Дело» РАНХиГС, 2017. - 288 с.

11. Вентцель Е.С., Овчаров Л.А. Теория вероятностей и ее инженерные приложения. Учеб. пособие для втузов. - 2-е изд., стер. - М.: Высш. шк., 2000. - 480 с: ил.

12. Страхування: Підручник За заг.ред В.Д. Базилевича. - К.: Знання, 2008 - 1019с. - (Київському національному університету імені Тараса Шевченка 175 років).

13. ISO/IEC 31010:2009 «Менеджмент ризику. Методи оцінки ризиків. (Risk management. Risk assessment techniques)».

14. Закон України «Про прийняття Конституції України і введення іiї в дію». Верховна Рада України; Закон від 28.06.1996 № 254/96-ВР. - Відомості Верховної Ради України (BBP), 1996, N 30, ст.142 [Електрон. ресурс] - URL: http://zakon3.rada.gov.ua/laws/show/254/96-вр. (дата звернення: 12.06.19)

15. Аронсон Э., Уилсон Т., Эйкерт Р. Социальная психология. Психологические законы поведения человека в социуме. - СПб.: Прайм-ЕВРОЗНАК, 2002. - 560 с.

16. GOV.UA. Державні сайти України [Електрон. ресурс] - Режим доступу: https://decentralization.gov.ua/gromada (дата звернення: 24.06.19).

17. GOV.UA. Державні сайти України [Електрон. ресурс] - Режим доступу: https://decentralization.gov.ua/news/9300 (дата звернення: 24.06.19).

18. Костенко В.О. Характеризація державного управління захистом населення у надзвичайних ситуаціях. Дис. ... к.держ. упр. : 25.00 .01 / В.О. Костенко. - ДРІДУ НАДУ. Дніпро, 2016. - 233 с.

19. Закон України від 02.03.2015 №222-VIII «Про ліцензування видів господарської діяльності» / Відомості Верховної Ради (ВВР), 2015, № 23, ст. 158.

20. Постанова Кабінету Міністрів України від 23.11.16р. № 852 «Деякі питання ліцензування господарської діяльності з надання послуг і виконання робіт протипожежного призначення» / Офіційний вісник України від 06.12.2016 - 2016 р., № 94, стор. 115 , стаття 3085 , код акта 83972/2016

21. Харчук А.I, Міллер О.В. Аудит з пожежної безпеки як елемент управління пожежним ризиком / Проблеми цивільного захисту: управління, попередження, аварійнорятувальні та спеціальні роботи: збірник тез II Всеукраїнської науково-практичної конференції. - Харків: Національний університет цивільного захисту України, 2013. - С. 69-72.

22. Кріса І.Я. Аудит з пожежної безпеки, як альтернативна оцінка пожежного ризику об'єкта господарювання / І.Я. Кріса, О.В. Міллер, А.І. Харчук, Ю.С. Шелюх // Пожежна безпека: Збірник наукових праць. - 2011. - № 19. - С. 61-65.

23. OHSAS $18001: 2007$. Системы менеджмента охраны здоровья и обеспечения безопасности труда. Требования. Перевод OHSAS 18001:2007 на русский язык и научнотехническое редактирование осуществил В.А. Качалов. Компания «СЕРТ Менеджмент» с УИК Интерсертифика-TUV совместно с TUV Thüringen, 2007. - 34 с.

24. Международный стандарт ISO 19011:2011. Руководство по аудиту систем менеджмента «Guidelines For Auditing Management Systems» [Електронний ресурс] Режим доступу: http://www.kachest-vo.ru/raz_4_standart/ISO_19011_2011.pdf (дата звернення: 31.05.19). 
25. Державна служба України з надзвичайних ситуацій. Портал електронних послуг [Електронний ресурс] - Режим доступу: https:/e-services.dsns.gov.ua/site/licensee-register (дата звернення 24.06.19).

26. Постанова Кабінету Міністрів України від 23.11.16р. № 852 «Деякі питання ліцензування господарської діяльності 3 надання послуг i виконання робіт протипожежного призначення» / Офіційний вісник України від 06.12.2016 - 2016 р., № 94, стор. 115, стаття 3085, код акта 83972/2016.

27. Гамалюк Б. М., Говорун С. В. Державне управління у сфері забезпечення

пожежної безпеки: особливості розслідування справ по пожежах, що спричинені порушенням вимог пожежної безпеки суб'єктами господарювання передбачених ст. 270 кримінального кодексу України. Державне управління: удосконалення та розвиток. 2019. № 5. - URL: http://www.dy.nayka.com.ua/?op=1\&z=1434 (дата звернення: 13.06.19). DOI: 10.32702/2307-2156-2019.5.24

\section{References:}

1. Saaty, T. \& Kerns, K. (1991). Analytycheskoe planyrovanye. Orhanyzatsyia system [Analytical planning. System organization] (Trans). Moscow, USSR: Radyo y Sviaz [in Russian]

2. Govorun , S.V. (2017). Prohnozuvannia neperedbachuvanykh ryzykiv u derzhavnomu upravlinnia systemoiu zabezpechennia pozhezhnoi bezpeky : sutnist ta metody [Prediction of unpredictable risks in public administration of the fire safety system: the essence and methods]. Proceedings from EPAU '17: VII Vseukrainska mizhvuzivska konferentsiia studentiv ta molodykh uchenykh «Stanovlennia publichnoho administruvannia v Ukraini» - The Eights All-Ukrainian inter-university conference of students and young scientists «Establishment of public administration in Ukraine» (pp.22-24). Dnipro, Ukraine: DRIDU NADU [in Ukrainian].

3. Rozporiadzhennia Kabinetu Ministriv Ukrainy № 61-r vid 25.01.2017 roku. Pro skhvalennia Stratehii reformuvannia systemy Derzhavnoi sluzhby Ukrainy z nadzvychainykh sytuatsii [Order of the Cabinet of Ministers of Ukraine About approval of the Strategy of reforming the system of the State Service of Ukraine for Emergencies from January 252017 , No.61-r] (2017, January 25). Retrieved http://search.ligazakon.ua/__doc2.nsf/link1/KR170061.html [in Ukrainian]

4. Zakon Ukrainy Pro osnovni zasady derzhavnoho nahliadu (kontroliu) u sferi hospodarskoi diialnosti [Law of Ukraine On the Basic Principles of State Supervision (Control) in the Sphere of Economic Activity] (2007, June 25). Ofitsiinyi visnyk Ukrainy - Official Bulletin of Ukraine, from June 252007 - 2007, No. 44, p. 12, article 1771, code of the act 40114/200 vid 25.06.2007 - 2007 [in Ukrainian]

5. Govorun, S. V. (2019). Derzhavne upravlinnia u sferi zabezpechennia pozhezhnoi bezpeky v Ukraini: aspekty instytutsiinoho rozvytku [Public administration in the field of fire safety in Ukraine: aspects of institutional development]/ Candidate's thesis. Lviv: LRIDU NADU [in Ukrainian]

6. Saaty, Tomas L. (2008). Pryniatye reshenyi pry zavysymostiakh y obratnykh sviaziakh: Analytycheskye sety [Making decisions in dependencies and inverse relationships: Analytical networks.] (A.V. Andreichikov, O.N. Andreichikova. Trans). Moscow, Russian Federation: Publishing house LKI [in Russian]

7. Tiuky, J. (1981). Analyz rezultatov nabliudenyi. Razvedochnыi analyz [Analysis of the results of observations. Exploratory analysis] (V.F. Pisarenko. Trans). Moscow, USSR: Publishing house «Mir» [in Russian]

8. $\quad$ Serebrovskyi, A.N., Oksanych, Y.N., Eremenko, T.K., Pylypenko, Yu.H. (2015). Veroiatnostnyi analyz bezopasnosty pry otsenyvanii stepeny pozharnoi opasnosty obyekta 
[Probabilistic safety analysis in assessing the degree of fire hazard of an object]. Naukovyi visnyk UkrNDIPB - Scientific Bulletin of UkrNISPB, 1 (31), 46-55 [in Russian]

9. Heizenberg, W. (1989). Fyzyka y fylosofyia. Chast y tseloe [Physics and Philosophy. Part and whole] (Trans). Moscow, USSR: Nauka [in Russian]

10. Gylboa, Ytskhak. (2017). Kak pryniat nayluchshee reshenye. Teoryia pryniatyia reshenyi na praktyke [How to make the best decision. The theory of decision-making in practice] (N.V. Shilova. Trans). E. Levina and V.P. Busygina (Ed.). Moscow, Russian Federation: Publishing House «Delo» RANHiGS [in Russian]

11. Venttsel E.S., Ovcharov L.A. (2000). Teoryia veroiatnostei y ee ynzhenernыe prylozhenyia [Theory of probabilities and its engineering applications] (2nd ed., rev.). Moscow, Russian Federation: Vysshaia shkola [in Russian]

12. Bazylevych, V.D. (Eds.). (2008). Strakhuvannia: Pidruchnyk [Insurance: Textbook]. Kyiv, Ukraine: Znannia [in Ukrainian]

13. Menedzhment ryzyku. Metody otsinky ryzykiv [Risk management. Risk assessment techniques] (2009). ISO/IEC 31010:2009 [in Ukrainian]

14. Zakon Ukrainy Pro pryiniattia Konstytutsii Ukrainy i vvedennia yii v diiu. Zakon vid 28.06.1996 № 254/96-VR. [The Law of Ukraine On Adoption of the Constitution of Ukraine and its Entry into Force. From June 28 1996, No. 254/96-BP. (1996, June 28). Vidomosti Verkhovnoi Rady Ukrainy (VVR) - Bulletin of the Verkhovna Rada (VVR), 1996, No. 30, p.142 Retrievd from: http://zakon3.rada.gov.ua/laws/show/254/96 [in Ukrainian]

15. Aronson Э., Uylson T., \& Эikert R. Sotsyalnaia psykholohyia. Psykholohycheskye zakony povedenyia cheloveka $\mathrm{V}$ sotsyume [Social psychology. Psychological laws of human behavior in society]. SPb, Russian Federation: PrimeEVROZNAK [in Russian]

16. GOV.UA. State sites of Ukraine [GOV.UA. Derzhavni saity Ukrainy]. https://decentralization.gov.ua/gromada. Retrieved from: https://decentralization.gov.ua/gromada [in Ukrainian]

17. GOV.UA. Derzhavni saity Ukrainy [GOV.UA. State sites of Ukraine]. https://decentralization.gov.ua/news/9300. https://decentralization.gov.ua/news/9300 [in Ukrainian]

18. Kostenko, V.O. (2016). Kharakteryzatsiia derzhavnoho upravlinnia zakhystom naselennia u nadzvychainykh sytuatsiiakh [Characterization of state management of population protection in emergencies]. Candidate's thesis. Lviv: DRIDU NADU [in Ukrainian]

19. Zakon Ukrainy Pro litsenzuvannia vydiv hospodarskoi diialnosti vid 02.03.2015 №222-VIII [Law of Ukraine On Licensing Types of Economic Activities from 02.03.2015 No. 222-VIII] (2015, March 02). Vidomosti Verkhovnoi Rady (VVR) - Bulletin of the Verkhovna Rada (VVR), 2015, No.23, Art. 158 [in Ukrainian]

20. Postanova Kabinetu Ministriv Ukrainy vid 23.11.16r. № 852 Deiaki pytannia litsenzuvannia hospodarskoi diialnosti z nadannia posluh i vykonannia robit protypozhezhnoho pryznachennia [Resolution of the Cabinet of Ministers of Ukraine dated 23.11.16. № 852 Certain issues of licensing of economic activities for the provision of services and performance of works of fire-prevention purposes] (2016, November 23). Ofitsiinyi visnyk Ukrainy - Official bulletin of Ukraine, dated 06.12.2016 - 2016, No. 94, p. 115, article 3085, code of act 83972/2016 [in Ukrainian]

21. Kharchuk, A.I, \& Miller, O.V. (2013). Audyt z pozhezhnoi bezpeky yak element upravlinnia pozhezhnym ryzykom [Fire safety audit as an element of fire risk management]. Proceedings from AUSRC '13: II Vseukrainskoi naukovo-praktychnoi konferentsii «Problemy tsyvilnoho zakhystu: upravlinnia, poperedzhennia, avariino-riatuvalni ta spetsialni roboty» - 2nd All-Ukrainian Scientific and Practical Conference «Civil defense issues: management, 
prevention, emergency and rescue and special work» (pp. 69-72). Kharkiv, Ukraine: National University of Civil Protection of Ukraine [in Ukrainian]

22. Krisa, I.Ya. (2011). Audyt z pozhezhnoi bezpeky, yak alternatyvna otsinka pozhezhnoho ryzyku obiekta hospodariuvannia [Fire safety audit as an alternative assessment of the fire risk of the facility]. Pozhezhna bezpeka: Zbirnyk naukovykh prats - Fire safety: Collection of scientific works, 19, 61-65 [in Ukrainian]

23. Systemy menedzhmenta okhrany zdorovia y obespechenyia bezopasnosty truda. Trebovanyia. [Health and safety management systems. Requirements] (2007). OHSAS 18001:2007. Kompanyia «SERT Menedzhment» s UYK Yntersertyfyka-TUV sovmestno s TUV Thüringen [in Russian]

24. Rukovodstvo po audytu system menedzhmenta [Guidelines For Auditing Management Systems] (2011). ISO 19011:2011. [Retrieved from: http://www.kachestvo.ru/raz_4_standart/ISO_19011_2011.pdf [in Russian]

25. Derzhavna sluzhba Ukrainy $\mathrm{z}$ nadzvychainykh sytuatsii. Portal elektronnykh posluh [State Service of Emergency of Ukraine. Electronic Services Portal. eservices.dsns.gov.ua/site/licensee-register. Retrieved from: https:/eservices.dsns.gov.ua/site/licensee-register [in Ukrainian]

26. Postanova Kabinetu Ministriv Ukrainy Deiaki pytannia litsenzuvannia hospodarskoi diialnosti z nadannia posluh i vykonannia robit protypozhezhnoho pryznachennia vid 23.11.16r. № 852 [Resolution of the Cabinet of Ministers of Ukraine Certain issues of licensing of economic activities for the provision of services and performance of works of fireprevention purposes from 23.11.16. № 852] (2016, November 23). Official bulletin of Ukraine Ofitsiinyi visnyk Ukrainy 06.12.2016 - 2016, No. 94, p. 115, article 3085, code of act 83972/2016 [in Ukrainian]

27. Hamaliuk, B. M., \& Govorun, S. V. (2019). Derzhavne upravlinnia u sferi zabezpechennia pozhezhnoi bezpeky: osoblyvosti rozsliduvannia sprav po pozhezhakh, shcho sprychyneni porushenniam vymoh pozhezhnoi bezpeky subiektamy hospodariuvannia peredbachenykh st. 270 kryminalnoho kodeksu Ukrainy [State management in the field of fire safety: features of investigation of cases on fires that are caused by violations of fire safety requirements by economic entities provided for in Art. 270 of the Criminal Code of Ukraine]. Derzhavne upravlinnia: udoskonalennia ta rozvytok - Public administration: improvement and development. 5 - Retrieved from: http://www.dy.nayka.com.ua/?op=1\&z=1434 DOI: 10.32702 / 2307-2156-2019.5.24 [in Ukrainian] 